\title{
ELECTRONIC REVERSE AUCTIONS IN PUBLIC CONSTRUCTION PROCUREMENT - EMPIRICAL EVIDENCE FROM THE CZECH REPUBLIC
}

\begin{abstract}
T.HANÁK ${ }^{1}$
Electronic reverse auctions (e-RAs) are considered to be an effective tool for negotiating tender prices and achieving cost savings. Furthermore, if multicritera evaluation is used, it can be expected that e-RAs will also contribute to achieving benefits in other areas, e.g. helping to minimize life-cycle costs. This study aims to analyse the mutual relationships between selected e-RA variables. More specifically, correlation analysis is applied to explore real e-RA data representing public tenders for construction work. This study's findings reveal that the correlations examined are generally weak or very weak. Furthermore, it has been found that the value of correlation coefficients varies depending on the type of structure, and that public tenders are usually evaluated solely on the basis of the criterion of the lowest bid price. Recommendations for public authorities in using e-RAs in the role of the buyer are also provided at the end of this paper.
\end{abstract}

Keywords: competition construction, electronic reverse auction, evaluation, public procurement, savings

\section{INTRODUCTION}

The procurement stage is an integral part of a construction investment project. Its importance is even more significant today, since purchasing management impacts the success of the institution. Schoenherr et al. [23] actually consider it a tool that brings on a competitive advantage. Furthermore, procurement planning is among the key process areas of contract management, as ascertained by Marović et al. [22].

\footnotetext{
${ }^{1}$ Assoc. Prof., PhD., Eng., Brno University of Technology, Faculty of Civil Engineering, Veveři 95, 60200 Brno, Czech Republic, e-mail: hanak.t@fce.vutbr.cz
} 
In general, construction projects typically feature a high degree of complexity; it is difficult to manage them and ensure that project goals such as cost, time, or quality are achieved. A broader range of project assessment criteria exists [4], but the three above-mentioned criteria have been extensively studied and can be considered the most crucial ones. When speaking about public procurement, the costs of construction are of main significance, since the selection of suppliers is often based solely on the criterion of the lowest bid price (as confirmed in the Czech Republic as well as in Poland in [13]).

Efficient procurement contributes to negotiating prices that are favourable to the investor. It is therefore of particular interest for investors to seek various tools or solutions that will help save public investment funds. From this perspective, public authorities (who play the role of public investors) should consider the option of adopting electronic reverse auctions (e-RAs) and integrating them into their internal procurement processes.

This contribution therefore deals with the use of e-RAs within public construction procurement. More specifically, the main aim here is to explore the relationships between selected auction variables (the best bid before e-RA, the number of suppliers who have submitted their bids, the amount of relative savings, and the number of changes of bids per one submitted bid) by using correlation analysis, as well as to explore the evaluation method of the bids themselves. The first part of this contribution introduces the applicability of e-RAs and related benefits and barriers, the second part describes the methodology used, the third part looks at the results and discusses them, and fourth and last part summarizes the main findings of the present study.

\section{E-RA APPLICABILITY AND RELATED BENEFITS AND BARRIERS}

It should be noted that e-RA application should be subject to proper decision-making, because e-RAs are not suitable for all purchasing situations. In particular, the following basic prerequisites should be satisfied as recommended by Beall et al. [3], Hawkins et al. [14], Kumar and Maher [18], Mabert and Skeels [21], Wamuziri and Abu-Shaaban [28]: 1) the subject of the purchase (with regard to legal requirements concerning e.g. the bill of quantities [16]) can be clearly specified; 2) there is a sufficient supply base; 3) expected savings are attractive; 4) the personnel involved in purchasing is experienced; 5) adequate hardware and software is available on the demand side as well as on the supply side; 6) the purchase amount is sufficiently attractive; and 7) a high-quality e-RA system will be used. 
E-RAs are used mostly due to the fact that they help achieve financial savings in comparison to traditional (non-e-RA-supported) procurement. From the buyer's point of view, the price negotiation is very effective since prospective suppliers are submitting their bids in an electronic way and during the so-called competition round they can see the bids of other bidders (or at least the best bid offered in the tender). Therefore, during the competition round, all bidders have an equal opportunity to modify their bids and win the contract. However, such savings can be considered just "gross savings", because related saving losses (both direct and indirect, such as changes in price through post-online auction negotiation and fees paid to the online reverse auction service company, respectively) should be taken into account as well, as emphasized by [11].

A necessary condition for meaningful use of e-RAs is the active participation of at least two bidders. The academic literature notes that the higher the number of bidders, the higher the level of competition created, and, consequently, the higher the fall in bid prices [24]. According to [27], four bidders already create a sufficiently strong competitive environment in the auction. Besides savings, auctions are also beneficial by contributing to time savings [6] and making the purchasing process more transparent [5]. On the other hand, e-RAs may harm the buyer-supplier relationship [6] and a significant fall in the bid price may be associated (during the construction phase) with a decrease of the quality of delivery. It is therefore important to specify qualitative requirements as well [26]. In connection with e-RA use, unethical behaviour by participants is also mentioned by researchers [6], [7]. In the construction industry, this phenomenon relates mainly to the submission of abnormally low bids. This issue deserves appropriate attention in order to assist in correctly detecting such abnormally low bids in public tenders [9], [2]. The risk that unreliable competitors will participate may be reduced by proper qualification procedures, although these cannot be discriminatory in public tenders, and if too excessive they decrease competitiveness and promote potential collusions among the limited number of suppliers [8]. The investor should also be aware of a consequent increase in investment costs, i.e. cost overruns during the construction phase [15]. From the perspective of sustainability, the e-RA enables the use of multicriteria evaluation, which facilitates the effort of implementing a life-cycle costs approach of public tenders. Life-cycle costs are important for various types of structures (e.g. buildings [12] or transport infrastructure [25]) and applying such an approach is recommended by e.g. the new Czech Act no. 134/2016 Coll. "On Public Procurement" [1]. Accordingly, the evaluation of bids should not always be related solely to the lowest bid price; other relevant criteria which contribute to achieving the best value for the money as well as for society must be examined. 
Finally, it should be stated, that relevant laws in individual countries may regulate the rules of e-RA use in different ways, for example, imposing an obligation to use them or to restrict their use depending on the value or type of contract. Similarly, even the terminology is not uniform, since e-RAs are referred e.g. to as "electronic auctions" in the Czech Republic but as "electronic bidding" in Poland [17].

\section{RESEARCH METHODOLOGY}

Data was collected from the internal database of one of the leading e-RA service companies in the Czech Republic. The research sample consists of 267 records of completed e-RAs relating to tenders for public works. It was required that each record is described through the following set of variables: the number of prospective suppliers (PRS), the number of suppliers who have submitted their bids (SSB), the best bid before the e-RA (BBA), the winning bid (i.e. the bid after the comparison round, WIB), the number of bid changes during the comparison round ( $\mathrm{BCH})$ and the type of evaluation criteria (lowest price/multicriteria evaluation). Outliers have been removed by using a boxplot.

In particular, this study focuses on tenders, where the subjects of contracts are delivery of construction works for schools, transport infrastructure, and municipal residential buildings (hereinafter referred to as "buildings"). Accordingly, individual e-RA records have been grouped under three categories.

Furthermore, the amount of relative savings (RES) has been computed by using the following equation:

$$
\text { RES }=\left(1-\frac{\mathrm{WIB}}{\mathrm{BBA}}\right) * 100 \%
$$

and the variable number of change of bids per one submitted bid (BCB) is defined as:

$$
B C B=\frac{B C H}{S S B}
$$

In the next step, correlation analysis of selected e-RA variables (SSB, BBA, RES and BCB) was performed separately for each category in order to evaluate their mutual relationships. To provide a 
better understanding of the data, descriptive statistics of selected variables and histograms are provided within the results.

\section{RESULTS AND DISCUSSION}

\subsection{ANALYSIS OF E-RA VARIABLES}

The results of the correlation analysis (r, correlation coefficient) for each category are given in Tables $1-3$ in the form of a correlation matrix. It can be seen that the highest correlation coefficient exists between the variables RES and BCB. It can be expected that each change of a submitted bid contributes to a decrease in the bid price and therefore results in higher savings. With regard to the attractiveness of the contract (expressed by its value, which corresponds to the BBA variable), it can clearly be seen that there is no relationship with the amount of savings achieved.

Table 1. Correlation matrix for the category Schools

\begin{tabular}{|c|c|c|c|}
\hline & BBA & RES & SSB \\
\hline RES & 0.060 & & \\
\hline SSB & 0.098 & 0.365 & \\
\hline BCB & -0.001 & 0.640 & 0.155 \\
\hline
\end{tabular}

Table 2. Correlation matrix for the category Transport Infrastructure

\begin{tabular}{|c|c|c|c|}
\hline & BBA & RES & SSB \\
\hline RES & 0.014 & & \\
\hline SSB & 0.262 & 0.180 & \\
\hline BCB & 0.041 & 0.696 & 0.034 \\
\hline
\end{tabular}

Table 3. Correlation matrix for the category Buildings

\begin{tabular}{|c|c|c|c|}
\hline & BBA & RES & SSB \\
\hline RES & -0.051 & & \\
\hline SSB & 0.340 & 0.131 & \\
\hline BCB & 0.002 & 0.378 & 0.080 \\
\hline
\end{tabular}


Therefore, it can be postulated that a higher amount of savings can be achieved for both large-scale as well as small-scale contracts. From the perspective of individual categories, a more interesting finding was revealed in relation to the SSB variable. The highest correlation coefficient between BBA and SSB was found for the category Buildings, while the lowest was found for the category Schools $(r=0.340 ; r=0.098$ respectively). This phenomenon can be attributed to the fact that suppliers who deliver within the category of Buildings are more sensitive to the amount of the contract, and therefore it can be expected that with increasing BBA value there is stronger potential for a competitive environment.

In this relation, Lesniak [19] has proved that both the type of work and the value of the project are among the important factors influencing bidding decisions. To understand the causes of such difference in $r$, additional research should be carried out, because the details of work on schools have specific features, such as the need for the work to be completed within a limited time during school holidays (in order to ensure uninterrupted teaching activity in educational facilities).

Regarding the relation between RES and SSB variables, the highest correlation coefficient $(r=0.365)$ has been observed for Schools. This indicates that within the "School" sector, the amount of savings achieved is more dependent on the number of bidders than for Transport Infrastructure and Buildings. Within these two categories, the amount of savings is not so dependent on the number of submitted bids, and therefore it can be expected that higher savings can potentially be achieved even with a lower number of bidders.

However, if the strength of the examined association between RES and SSB is labelled, then it should be noted that this correlation for Schools is merely "low" (as $\mathrm{r}$ falls in $<0.2 ; 0.39>$ ). From this perspective, it can be concluded that neither the attractiveness of the contract nor the level of competitiveness (measured by BBA and SSB respectively) has a significant effect on the main e-RA outcome, i.e. the amount of savings achieved (RES). The only strong correlation exists between RES and BCB (with the exception of the Buildings category).

Table 4. Descriptive statistics of the research sample from the SSB perspective

\begin{tabular}{|c|c|c|c|}
\hline Category & Schools & Transport infrastructure & Buildings \\
\hline $\mathrm{n}$ & 91 & 60 & 116 \\
\hline Mean & 3.473 & 3.683 & 3.948 \\
\hline Median & 3.000 & 3.000 & 4.000 \\
\hline StDev & 1.721 & 2.143 & 1.915 \\
\hline
\end{tabular}




\begin{tabular}{|c|c|c|c|}
\hline Minimum & 1.000 & 1.000 & 1.000 \\
\hline Maximum & 12.000 & 12.000 & 12.000 \\
\hline
\end{tabular}

The SSB variable should also be explored in greater detail. Table 4 shows basic descriptive statistics for the SSB. From the Mean and Median values, one can clearly see that there are no significant discrepancies between the examined categories. For the Schools and Transport Infrastructure categories the median is 3 , while for the Buildings category the median is equal to 4 . With respect to [27], who recommend having at least 4 bidders in the e-RA, the reality of Czech public construction procurement is not so favourable towards an e-RA, as for all categories the number of suppliers who really submit their bids is slightly lower than 4 . It should therefore be recommended to public authorities that they communicate e-RAs actively to their supplier community, and make sufficient effort to obtain an adequate number of bidders in the e-RA.

Table 5. Descriptive statistics of the research sample from the RES perspective

\begin{tabular}{|c|c|c|c|}
\hline Category & Schools & Transport infrastructure & Buildings \\
\hline $\mathrm{n}$ & 91 & 60 & 116 \\
\hline Mean & 0.0873 & 0.0919 & 0.0991 \\
\hline Median & 0.0469 & 0.0493 & 0.0734 \\
\hline StDev & 0.1029 & 0.1089 & 0.0981 \\
\hline Minimum & 0.0000 & 0.0000 & 0.0000 \\
\hline Maximum & 0.3965 & 0.4022 & 0.3971 \\
\hline
\end{tabular}

Regarding the amount of realized savings (RES) among particular categories (Table 5), it has been observed that higher RES exists within the Buildings category. Even though the mean value varies between 0.0873 and 0.0991, a more significant difference was revealed for the Buildings category in terms of the median (0.0734). Such data indicates that, despite the lower correlation between RES and BCB, bidders are willing to lower their bids more than in the Schools and Transport Infrastructure categories. Higher RES are more likely to be seen for the Buildings category and, therefore, especially public tenders dealing with Buildings seem to be appropriate for e-RAs from this perspective. In any event, it should be noted that the results are discussed in relative terms (RES in \%). In absolute values, higher savings should be expected for Transport Infrastructure, since their expected value is usually higher than that of work on Schools and Buildings. 


\subsection{EVALUATION OF BIDS IN E-RAS}

It has been observed that an overwhelming majority of tenders (93.6\%) have been evaluated solely according to the bid price (awarding the contract to the lowest bidder). This finding reveals that public authorities do not take into account life-cycle costs (LCC; especially operation, renovation, and demolition costs). From this perspective, actual practice in the Czech Republic is not in accordance with the principles of sustainable development, which aim for, among other things, a decrease in energy consumption, and a reuse of building materials, thus protecting the environment. For example, in the case of residential buildings, operation costs should not be omitted, as hot water, cooling and heating systems, ventilation, and lightning [10] may subsequently incur a significant cost during building operation and negatively impact the environment. The main reason for using solely the bid price to evaluate bids is to avoid the need to have specific weight assigned to any partial criteria. It should be noted that there is insufficient experience with LCC implementation in public tenders, and therefore setting the correct weight for this analysis poses a substantial challenge.

Regarding this issue, a certain effort should be made in order to provide public authorities with guidelines for how to apply LCC as one of the bid evaluation criteria. More specifically, representative structures that will provide relevant information mainly about operation and maintenance costs and the lifetime of building elements (windows, roof, technical equipment, etc.) should be identified and monitored in an in-depth detail. Since buildings are long-term assets (their lifespan is quantified in decades), the estimates for future operation and maintenance costs will always be partially inaccurate (effects of inflation, credit policies, subsidies, etc.). By monitoring and evaluating representative structures, it can be ensured that inaccuracies of cost estimates are minimized to a tolerable level. Furthermore, a design \& build approach [20] should also be promoted.

Finally, the dependence of RES on the bid evaluation method is explored. Data (belonging to the whole sample) presenting the relative distribution of RES values for both bid price and multicriteria evaluation is presented in Figure 1 (histogram).

Since the amount of data for multicriteria evaluation is limited, no statistical test is used. However, from the data presented in Figure 1, no significant decrease of RES can be observed as a consequence of multicriteria evaluation. Accordingly, concerns about lower bid price reductions in e-RAs under multicriteria evaluation of bids are not justified. This should be attributed to the fact that even with multicriteria evaluation the bid price variable holds the highest weight among the set of criteria [13]. 
Fig. 1 indicates that a really high portion of e-RAs has brought about only a very small amount of savings. Taking this into account, if public authorities require financial benefit from e-RA use, they should complete a sufficient number of e-RAs annually in order to cover all auction costs and losses.

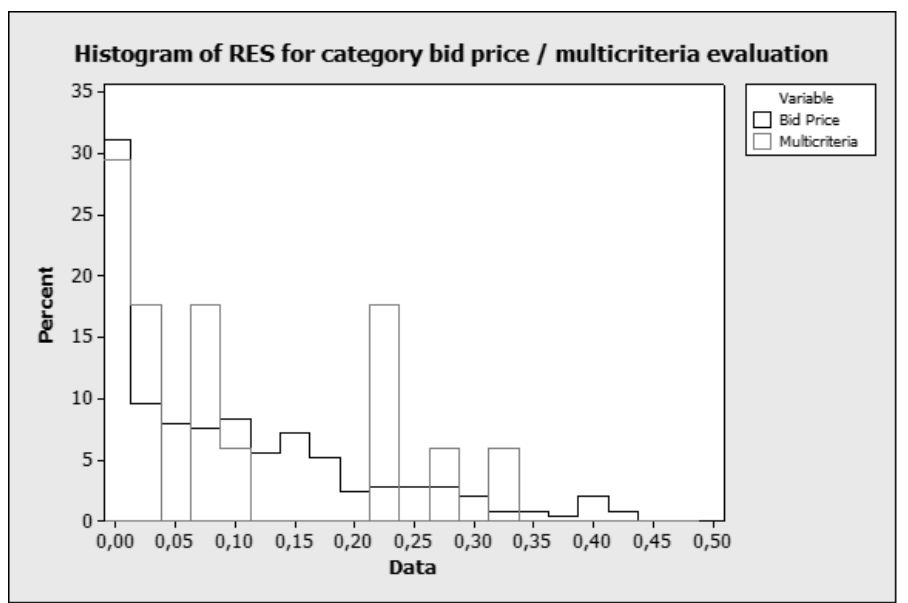

Fig. 1. Histogram of RES for category bid price and multicriteria evaluation

\section{CONCLUSION}

This research has shown that achieving attractive savings through e-RAs in public construction procurement is not something automatic. For a large number of the research sample, the amount of savings is relatively small. A strong effect of the number of bidders in the tender on the amount of realized savings has not been confirmed, but this is probably due to the fact that construction e-RA tenders suffer from low bidder participation. Public authorities should therefore communicate the presence of active e-RAs to suppliers' committees effectively in order to increase their willingness to submit bids. Research results did not confirm any medium or strong correlation of e-RA variables, except for the relation between RES and BCB variables.

Future trends in public procurement will restrict bids from being evaluated solely on the basis of the lowest bid price, the currently prevailing evaluation method in the Czech Republic. In this regard, legislative as well as technical support should be provided to public authorities in order to adopt the LCC approach in public construction procurement and successfully implement it as an integral part of e-RAs. 
This research has two main limitations. First, it is based only on quantitative analysis. In order to understand the causes and effects better, subsequent qualitative research should be performed. Secondly, since the amount of e-RA data with multicriteria evaluation is limited, a more detailed analysis of this aspect was not possible. Future research should focus not just on multicriteria evaluation, but also on the occurrence of abnormally low bid prices, qualification prerequisites, and the LCC approach. The subject of this research was a narrow area relating e-RA variables within public construction procurement. With a more complex approach, additional variables can be taken into account, which could then enable better pattern analysis regarding the study area.

The author expresses his acknowledgment to the project No. LO1408 "AdMaS UP - Advanced Materials, Structures and Technologies", supported by Ministry of Education, Youth and Sports under the "National Sustainability Programme I", Czech Republic for the excellent cooperation during paper preparing.

\section{REFERENCES}

1. Act no. 134/2016 Coll., on Public Procurement (the Czech Republic)

2. P. Ballesteros-Pérez, M. Skitmore, R. Das, M.L. Del Campo-Hitschfeld, "Quick abnormal-bid-detection method for construction contract auctions". Journal of Construction Engineering and Management, 141:7, 2015 .

3. S. Beall, C. Carter, P. Carter, T. Germer, T. Hendrick, S. Jap, L. Kaufmann, D. Maciejewski, R. Monczka, K. Peterson, "The Role of Reverse Auctions in Strategic Sourcing", CAPS Research Report, 2003.

4. I. Burcar Dunovic, M. Radujkovic, M. Vukomanovic, "Internal and external risk based assessment and evaluation for the large infrastructure projects", Journal of Civil Engineering and Management, 22:5, pp. 673682, 2016.

5. M.C.J. Caniëls, E.M. van Raaij, "Do all suppliers dislike electronic reverse auctions?”, Journal of Purchasing and Supply Management, 15:1, pp. 12-23, 2009.

6. C.R. Carter, L. Kaufmann, S. Beall, P.L. Carter, T.E. Hendrick, K.J. Petersen, "Reverse auctions - grounded theory from the buyer and supplier perspective", Transportation Research Part E: Logistics and Transportation Review, 40:3, pp. 229-254, 2004.

7. M.H. Charki, E. Josserand, N.B. Charki, "Toward an ethical understanding of the controversial technology of online reverse auctions", Journal of Business Ethics, 98:1, pp. 17-37, 2011.

8. C.K. Chau, W.L. Lee, J. Burnett, M.Y. Law, T.M. Leung, "On the study of the impact of relaxing the prequalification requirements on the competitiveness in the supply of water pumps", Building and Environment, 40:2, pp. 213-219, 2005.

9. P.L. Conti, L. De Giovanni, M. Naldi, "A rank-and-compare algorithm to detect abnormally low bids in procurement auctions", Electronic Commerce Research and Applications, 11:2, pp. 192-203, 2012.

10. G.K.C. Ding, "Sustainability assessment of residential development - An Australian experience", International Journal of Construction Management, 10:2, pp. 19-32, 2010.

11. M.L. Emiliani, D.J. Stec, "Realizing savings from online reverse auctions", Supply Chain Management: An International Journal, 7:1, pp. 12-23, 2002.

12. G. Han, J. Srebric, E. Enache-Pommer, "Variability of optimal solutions for building components based on comprehensive life cycle cost analysis", Energy and Buildings, 79, pp. 223-231, 2014.

13. T. Hanák, J. Korytárová, R. Kozik, E. Radziszewska-Zielina, "Exploration of Contractor Evaluation Process in the Management of Public Works Contracts", Project Management as a Spectrum of Scientific Problems in Engineering and Management. Wroclav: WSOWL, pp. 55-65, ISBN: 978-83-63900-63-2, 2015.

14. T. Hawkins, A. Coyne, B. Hudgens, "Exploring the Application of Electronic Reverse Auctions in Federal Procurement: Removing Barriers to Unleash Savings”, Air Force Journal of Logistics, 34:1, pp. 2-15, 2010. 
15. V. Hromádka, J. Korytárová, L. Kozumplíková, P. Adlofová, D. Bártů, M. Špiroch, "Risk of megaprojects in transport infrastructure", Advances in Civil Engineering and Building Materials IV - 4th International Conference on Civil Engineering and Building Materials, pp. 223-228, 2015.

16. M. Juszczyk, R. Kozik, A. Lesniak, E. Plebankiewicz, K. Zima, "Errors in the preparation of design documentation in public procurement in Poland", Procedia Engineering, 85, pp. 283-292, 2014.

17. R. Kozik, E. Plebankiewicz, "Bid documentation in public procurement in Poland", Organization, Technology and Management in Construction · An International Journal, 5:1, pp. 712-719, 2013.

18. S. Kumar, M. Maher, “Are the temptations of online reverse auctions appropriate for your business?", Supply Chain Management: An International Journal, 13:4, pp. 304-316, 2008.

19. A. Lesniak, "Classification of the Bid/No bid criteria-factor analysis". Archives of Civil Engineering, 61(4), 79-90, 2015.

20. A. Lesniak, E. Plebankiewicz, K. Zima, "Design and build procurement system - Contractor selection", Archives of Civil Engineering, 58:4, pp. 463-476, 2012.

21. V.A. Mabert, J.A. Skeels, "Internet reverse auctions: Valuable tool in experienced hands", Business Horizons, 45:4, pp. 70-76, 2002.

22. I. Marović, D. Bošković, I. Gudac, "Process approach in modelling Croatian construction contract management practice”, International Journal for Engineering Modelling, 25:1-4, pp. 19-26, 2012.

23. T. Schoenherr, S.B. Modi, W.C. Benton, C.R. Carter, T.Y. Choi, P.D. Larson, M.R. Leenders, V.A. Mabert, R. Narasimhan, S.M. Wagner, "Research opportunities in purchasing and supply management", International Journal of Production Research, 50:16, pp. 4556-4579, 2012.

24. E. Sičáková-Beblavá, P. Klátik, M. Beblavý, "Ekonomické efekty elektronických aukcií na Slovensku”, Ekonomický časopis, 61:10, pp. 1067-1078, 2013.

25. J. Šelih, A. Kne, A. Srdić, M. Žura, "Multiple-criteria decision support system in highway infrastructure management", Transport, 23:4, pp. 299-305, 2008.

26. R. Tassabehji, W.A. Taylor, R. Beach, A. Wood, "Reverse e-auctions and supplier-buyer relationships: An exploratory study", International Journal of Operations and Production Management, 26:2, pp. 166-184, 2006.

27. S.M. Wagner, A.P. Schwab, "Setting the stage for successful electronic reverse auctions", Journal of Purchasing and Supply Management, 10:1, pp. 11-26, 2004.

28. S. Wamuziri, N. Abu-Shaaban, "Potential of reverse auctions in construction procurement", Proceedings $21 \mathrm{st}$ Annual ARCOM Conference, Association of Researchers in Construction Management, pp. 611-619, 2005. 


\section{LIST OF FIGURES AND TABLES:}

Fig. 1. Histogram of RES for category bid price and multicriteria evaluation

Fig. 1. Histogram RES dla kategorii cena oferty oraz ocena wielokryterialna

Tab. 1. Correlation matrix for the category Schools

Tab. 1. Matryca korelacji dla kategorii Szkoły

Tab. 2. Correlation matrix for the category Transport Infrastructure

Tab. 2. Matryca korelacji dla kategorii Infrastruktura Transportowa

Tab. 3. Correlation matrix for the category Buildings

Tab. 3. Matryca korelacji dla kategorii Budynki

Tab. 4. Descriptive statistics of the research sample from the SSB perspective

Tab. 4. Statystyka opisowa dla próbki badawczej z perspektywy SSB

Tab. 5. Descriptive statistics of the research sample from the RES perspective

Tab. 5. Statystyka opisowa dla próbki badawczej z perspektywy RES 


\section{ELEKTRONICZNE AUKCJE ODWROTNE W PUBLICZNYCH ZAMÓWIENIACH BUDOWLANYCH - DOWODY EMPIRYCZNE Z REPUBLIKI CZESKIEJ}

Słowa kluczowe: konkurencja budowlana, elektroniczna licytacja odwrotna, ocena, zamówienia publiczne, oszczędności

\section{STRESZCZENIE:}

Niniejsza praca omawia wykorzystanie elektronicznych aukcji odwrotnych (eRA) w sektorze publicznych zamówień budowlanych. Elektroniczne aukcje odwrotne są stosowane głównie dlatego, że wspierają oszczędności finansowe oraz, zwłaszcza w sektorze publicznym, sprawiają, że proces zakupowy jest bardziej przejrzysty. W szczególności, niniejsza praca ma na celu zbadanie związków pomiędzy wybranymi zmiennymi aukcji (najlepsza oferta przez eRA, liczba dostawców składających oferty, kwota względnych oszczędności oraz liczba zmian oferty na jedną złożoną ofertę). W tej relacji, wykorzystana jest analiza korelacyjna. Co więcej, niniejsze badanie zwraca również uwagę na metodę oceny stosowaną w eRA (najniższa cena oferty / ocena wielokryterialna).

Próbka badawcza składa się z 267 zapisów zrealizowanych eRA, dotyczących przetargów na publiczne projekty budowlane, indywidualne zapisy eRA zostały pogrupowane w trzech kategoriach (prace wykonane dla szkół, dla infrastruktury transportowej oraz dla miejskich budynków mieszkaniowych, zwanych dalej „budynkami”). Wyniki przedstawione są w formie matrycy korelacji. Aby jeszcze bardziej wesprzeć dyskusję, przedstawiono również wybrane statystyki opisowe próbki badawczej oraz histogramu.

W kwestii zmiennych eRA, najlepsza oferta przed aukcją oznacza przybliżoną wartość umowy, a tym samym, jej atrakcyjność dla dostawców, zmienne liczby dostawców, którzy złożyli oferty oznaczają poziom konkurencji w przetargu, a kwota oszczędności względnych wyraża wpływ kluczowych korzyści eRA.

Główne wyniki przedstawione w niniejszym badaniu są następujące:

- Najwyższa korelacja istnieje pomiędzy zmiennymi ‘kwota oszczędności względnych’ a ‘liczba zmian oferty na jedną złożoną ofertę’ (0.640, 0.696, 0.378 odpowiednio, dla szkół, infrastruktury transportowej oraz budynków).

- W kwestii atrakcyjności umowy (najlepsza oferta przed eRA), nie ma silnego lub średniego związku z osiągniętą kwotą oszczędności $(0.060,0.014,-0.051$, odpowiednio, dla szkół, infrastruktury transportowej oraz budynków).

- Istnieją różnice między kategoriami umów, w przypadku, gdy badany jest związek pomiędzy najlepszą ofertą przed eRA a liczbą dostawców, którzy złożyli oferty $(0.098,0.262,0.340$ odpowiednio, dla szkół, infrastruktury transportowej oraz budynków).

- Najwyższa korelacja $(\mathrm{r}=0.365)$ istnieje w kategorii szkół, pomiędzy kwotą oszczędności względnych a liczbą dostawców, którzy złożyli oferty. Niemniej jednak, ta korelacja, pomiędzy poziomem konkurencji a kwotą oszczędności, określona jest jako niska.

- Zdecydowana większość umów oceniana jest wyłącznie na podstawie ceny oferty. Zatem, ocena wielokryterialna jest wykorzystywana rzadko i stąd władze publiczne nie promują podejścia LCC (koszt cyklu życia) w zamówieniach publicznych. 
- Obawy o niższe obniżenie ceny oferty w eRA w ocenie wielokryterialnej nie są potwierdzone, jak widać na histogramie zmiennej oszczędności względnych dla kategorii cena oferty / ocena wielokryterialna (Rysunek 1).

- Znacząco wysoka część eRA przyniosła jedynie bardzo małą kwotę oszczędności.

- Wyższe oszczędności względne są bardziej prawdopodobne dla kategorii Budynki (Tabela 5).

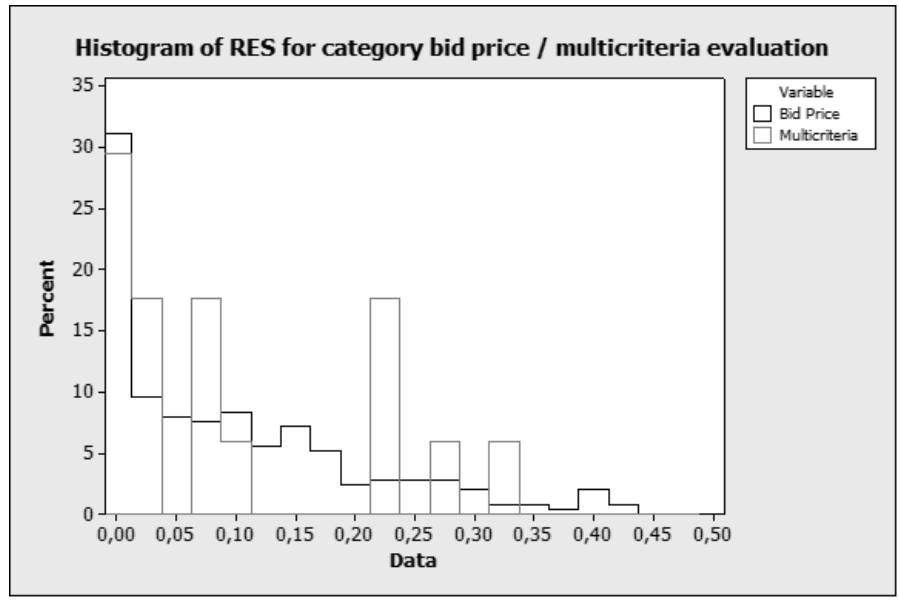

Rysunek 1: Histogram RES dla kategorii cena oferty oraz ocena wielokryterialna

Tabela 5. Statystyka opisowa dla próbki badawczej z perspektywy RES

\begin{tabular}{|c|c|c|c|}
\hline Kategoria & Szkoły & $\begin{array}{c}\text { Infrastruktura } \\
\text { transportowa }\end{array}$ & Budynki \\
\hline $\mathrm{n}$ & 91 & 60 & 0,0991 \\
\hline Średnia & 0,0873 & 0,0919 & 0,0734 \\
\hline Mediana & 0,0469 & 0,0493 & 0,0981 \\
\hline OdchSt & 0,1029 & 0,1089 & 0,0000 \\
\hline Minimum & 0,0000 & 0,0000 & 0,3971 \\
\hline Maksimum & 0,3965 & 0,4022 & 0,000 \\
\hline
\end{tabular}

Wyniki pracy pokazują, że badane korelacje są ogólnie słabe lub bardzo słabe. Na podstawie powyżej przedstawionych ustaleń, można zalecić władzom publicznym, by lepiej przekazywały istnienie eRA społeczności dostawców. W takim przypadku, kiedy podjęto wystarczające wysiłki, aby zdobyć odpowiednią liczbę oferentów, można oczekiwać wyższych potencjalnych oszczędności finansowych, jako, że osiągnięcie atrakcyjnych oszczędności nie jest czymś automatycznym. Co więcej, należy promować podejście LCC (zgodnie z zaleceniami UE). Z powodu braku doświadczenia w tej kwestii, władze publiczne powinny uzyskać wytyczne dotyczące zastosowania LCC jako jednego z kryteriów oceny ofert. W tym zakresie, stosowanie podejścia ,projekt \& budowa”, należy również poważnie rozważyć. 